\title{
Treatment Episode Indicator
}

National Cancer Institute

\section{Source}

National Cancer Institute. Treatment Episode Indicator. NCI Thesaurus. Code C102720.

An indication of whether this is the individual's first time being treated for a disease or

that they are receiving a subsequent treatment. 